\title{
Student Worksheet Based on Mind Mapping to Increase Activities and Learning Outcomes
}

\author{
Galih Nurcahyo, Rusijono \& Ketut Prastyo \\ Universitas Negeri Surabaya \\ Surabaya, Indonesia \\ galihnurcahyo6@gmail.com
}

\begin{abstract}
The purpose of this research is to develop student worksheet product based on cooperative model of mind mapping. The student worksheet is tested to find out its effectiveness in improving the activity and students' learning outcomes. student worksheet is developed based on the steps of cooperative model of mind mapping type that begins with the conveyor of competence, raising the problem, forming the group, reading out of the discussion, and ended by making the conclusion by the students. This research type is $R \& D$ research (Research and Development) with 4D model that includes define, design, develop, disseminate. The research design used is Quasi experimental with nonequivalent control group design. Instrument validation sheet, observation, test and questionnaire were used in the data collection. The result of the research shows that student worksheet developed by the cooperative model of mind mapping can increase activity and result of students' learning outcome of the fourth grader of elementary school.
\end{abstract}

\section{Keywords-Worksheet; Mind mapping; activity; learning outcome}

\section{INTRODUCTION}

As a facilitator, a teacher has an important role in the learning process in the class because the teacher has the task to plan and develop the learning starting from determining the model of learning and preparing the teaching materials for the students. One of the teaching materials that can be used is the Students' worksheet. Students' worksheet is an effective tool in learning because it can activate the role of students in the learning process [1]. However, preparing the students' worksheet used in the learning should be with the appropriate method, which aims to make the students easier in understanding the material being studied [2] [3]. Some materials or concepts that students learn must have different characteristics so that different methods need to be developed in accordance with the teaching materials [4]. In addition, during the preparation of the ideal students' activity sheet must comply with the standards set forth in the PP (Government Regulation) no. 19 the year 2005 article 43 points 5 on the national standard of education that contains the feasibility of content, language feasibility, graphic feasibility, and feasibility of serving.

However, the current and emerging students' worksheet is still far from the standard of feasibility. In addition, students' activity sheet implemented in the learning activities have not used the right method and just do the multiple choice questions and description for one semester. This is evidenced by the results of observations of researchers at SDN Pisang III which indicates that students' worksheet used by teachers is students' worksheet from one of the publishers. The students' worksheet contains material, multiple choice questions and essay that are less appropriate to the level of students' abilities, the material, and the problem is too abstract and less appropriate to the conditions in which students learn. In addition to the problems, exercises contained in the students' worksheet are all the answers contained in the material reading so that students just search and copy the answer.

From these observations researcher also found that the teachers at SDN Pisang III do not develop their own students' worksheet in order to do learning but prefer to buy instant students' worksheet purchased from the publisher. Whereas in the preparation of students' worksheet should be done by the teachers themselves, because teachers who know the condition and need of students, this is in accordance with Government Regulation No. 19 of 2005 article 20 stating that teachers should be able to develop teaching materials for the learning process, PP is clarified again in Permendiknas no 41 of 2007 on the standard of educational process that regulates the planning in the learning process requires for teachers in institutional-educational institutions to develop teaching materials. Some of the reasons teachers do not develop students' worksheet are: 1) teachers do not have the time to create students' worksheet independently, 2) schools do not provide budgets for development of teaching materials for teachers, 3) teachers are more preoccupied with school administration and 4) teacher's ignorance on how to develop students' worksheet.

Students' worksheet that is arranged monotonically and containing only the multiple choice questions as well as the one-semester purchased from the publisher, make the students feel bored in following the lesson. It can be seen when the researcher observed the learning process in grade IV SDN Pisang III. When the teacher asks the students to do the students' worksheet task, the students look less energized as shown by the expression of the students. On the other hand, the learning process impressed by only doing the students' 
worksheet and then correct the students work together so that student activity in learning tends to be very low. Yet, according to Paul B. Dierich learning activities can be visual activities, oral activities, listening activities, writing activities, drawing activities, motor activities, mental activities, and emotional activities. However, when students are facilitated learning by using students' worksheet purchased from publishers, they only saw some activities such as visual activities and writing activities.

Developing students' worksheet is better when the teachers or developers consider the activities that will be done by students. It is because the learning activity has its own benefits for students is to foster the spirit and motivation to learn, students will get the experience of learning directly, able to grow cooperation among students, avoid the activities memorize the material and can grow a disciplined person [5]. In addition, learning activities can also help students in achieving maximum learning outcomes [6] .

Based on Students' worksheet development issues that are still less than the feasibility and students' activity sheet content that contains only multiple choice questions that impact on low student activity and learning outcomes. Researchers took the initiative to develop students' worksheet and integrate with a cooperative model of mind mapping type to improve student activity and learning outcomes. The reason researchers combine the cooperative model of mind mapping type is that according to Saroj [7], Buzan [8], Ozgul keles [9] Mind mapping allows students to understand, create new ideas and build connections. In other words, mind mapping can facilitate students' understanding of what is learned and can connect between the material one with other materials. other than that mind mapping can make it easier for students to remember [8] - Nikhilumar D. Parikh [10], Melor, Yunus [11] also states with mind mapping students will be more creative in generating ideas. From some of the advantages of the mind, the mapping will be able to improve student learning outcomes.

The steps contained in the cooperative model of mind mapping type are also able to increase student learning activities. The following are cooperative model steps of mind mapping type; delivering competence, raising issues, forming groups, reading out the results of the discussion, making conclusions [4]. With the steps, the student will do many useful activities in the learning process.

\section{METHOD}

This research belongs to research and development or R \& D (Research and Development) type. Brog and Gall in Sugiyono [12] states that R\&D (Research and Development) is a process or method used to validate and float the product.

The research subjects in this study are students of grade IV SDN Pisang III Patianrowo Nganjuk, amounting to 40 students consisting of two classes. The location of this research is at SDN Pisang 3, located in Pisang village patianrowo district nganjuk.
The model used in developing worksheet based on the mind mapping type cooperative model is a 4-D model from Thiagarajan, et al (197: 45), in which there are four stages of mining, Define, Design, Development, Disseminate.

The experiments in this research used the design of Nonequivalent Control Group Design. The designs of this study were two groups selected: experimental group and control group. The two groups were then pretested and tested using a t-test aimed at testing differences in student learning outcomes. The result of the pretest is expected to yield the same or not much different result. After both groups were treated with different students' activity sheet, the experimental group and the control group performed posttest and tested using the t-test. If there is a difference where the experimental class is higher than the control class, then it can be said students' worksheet based on the cooperative model of mind mapping type effective. However, if the experimental class is smaller than the control class, it can be said that students' worksheet based on the cooperative model of mind mapping type is not effective. Here is the design of this research:

TABLE 1 NONEQUIVALENT CONTROL GROUP DESIGN

\begin{tabular}{llll} 
Treatment group & $O 1$ & $x$ & $\mathrm{O} 2$ \\
\cline { 2 - 4 } Control group & & & \\
\hline
\end{tabular}

The instruments used in this research are the validation sheet, the observation sheet, the test, and the questionnaire. Validation sheet used to know the validity of Students' worksheet developed, observation sheet used to know the implementation of learning using Students' activity sheet based mind mapping model and to know the student activity in learning. The test is used to determine student learning outcomes after and before using Students' worksheet based on the cooperative model of mind mapping type. Meanwhile, the questionnaire is used to know the student's response to using the developed students' worksheet.

\section{RESULTS AND DISCUSSION}

The results of this study include four parts namely the validity of students' worksheet, students' worksheet practicality, student activeness during learning and the effectiveness of students' worksheet and the result:

\section{Students' worksheet validity Based on the cooperative model of mind mapping type}

TABLE 1I STUDENTS' WORKSHEET VALIDATION BASED COOPERATIVE MODEL TYPE MIND MAPPING

\begin{tabular}{|c|c|c|c|c|}
\hline No & Expert & Score & Percentage & Category \\
\hline 1 & Expert 1 & 123 & $92.4 \%$ & $\begin{array}{c}\text { It can be used with little } \\
\text { revision }\end{array}$ \\
\hline 2 & Expert 2 & 120 & $90.2 \%$ & $\begin{array}{c}\text { It can be used with little } \\
\text { revision }\end{array}$ \\
\hline
\end{tabular}


From the validation result given by the expert on students' worksheet based on cooperative model of mind mapping type, it can be concluded that students' worksheet is feasible to be used because only a few revisions and the percentage of assessment reaches $90 \%$.

\section{Students' worksheet-Based Practices Cooperative model of mind mapping type}

TABLE III.THE RESULTS OF THE IMPLEMENTATION STUDENTS WORKSHEET BASED ON COOPERATIVE MODEL OF MIND MAPPING TYPE

\begin{tabular}{|c|c|c|c|c|c|}
\hline \multirow{2}{*}{ Meeting } & \multicolumn{2}{|c|}{ Score } & \multirow{2}{*}{ Average } & \multirow{2}{*}{ Percentage } & Category \\
\cline { 2 - 6 } & Ob 1 & Ob 2 & & & \\
\hline 1 & 36 & 35 & 35.5 & $87.5 \%$ & Very High \\
\hline 2 & 37 & 38 & 37.5 & $92.5 \%$ & Very High \\
\hline 3 & 38 & 39 & 38.5 & $95 \%$ & Very High \\
\hline 4 & 39 & 40 & 39.5 & $98.7 \%$ & Very High \\
\hline 5 & 40 & 40 & $40 \%$ & $100 \%$ & Very High \\
\hline Average & & & 37.17 & $94 \%$ & Very High \\
\hline
\end{tabular}

From table 2 above, it can be concluded that the implementation of learning with students' worksheet based on mind mapping is very good. It is seen in the average observer observation of the learning process which reached 94\%. In addition to observation of the learning process, students' worksheet practicality can be known through student response after completion in the learning process. The following table presented the results of student responses to students' worksheet based on mind mapping:

\section{DIAGRAM 1 STUDENTS' RESPONSE}

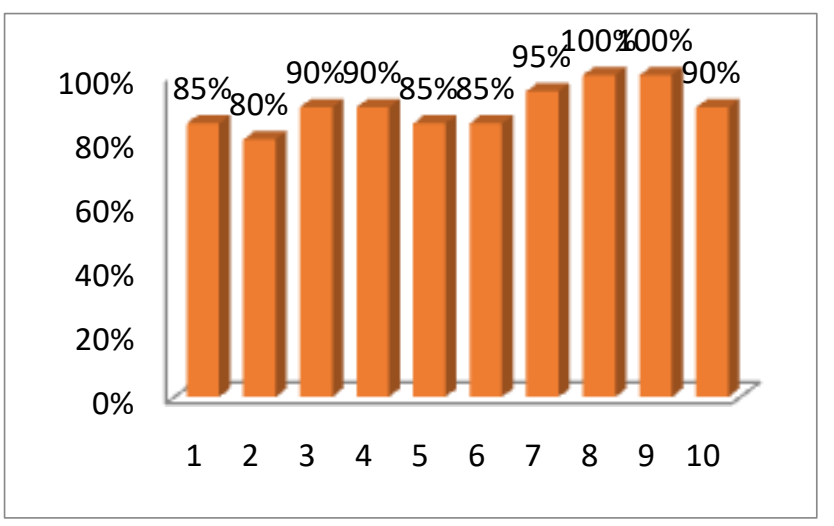

From the diagram 1 above, it can be seen that: 1) $85 \%$ of students can understand the material in students' worksheet based on cooperative model mind mapping 2) $80 \%$ of students can understand the picture in the cooperative model based cooperative model of mind mapping type 3) $90 \%$ of students understand the problems in students' worksheet based on cooperative mind mapping model 4) $90 \%$ of students can understand the questions in students' worksheet based on cooperative mind mapping model 5) $85 \%$ students are able to understand each sentence in students' worksheet based on cooperative mind mapping model 6) $85 \%$ of students prefer color and picture design on students' worksheet based on cooperative mind mapping model 7) $95 \%$ of students liked front cover design of cooperative model based on mind mapping 8) $100 \%$ student feel pleasant working on problems in cooperative model based on mind mapping 9) 100\% student feels happy in preparing mind mapping 10) $90 \%$ of students feel happy to attend lessons with students' worksheet based on cooperative mind mapping model.

Based on the observer's evaluation of the learning using Students' worksheet based on the cooperative model of mind mapping type and the response of the students after learning to use the students' worksheet, it can be concluded that cooperative model of mind mapping type is practically used in learning.

\section{The active participation of students in learning}

TABLE IV STUDENTS' ACTIVE PARTICIPATION IN LEARNING

\begin{tabular}{|c|c|c|}
\hline \multirow{2}{*}{ Meeting } & \multicolumn{2}{|c|}{ Percentage } \\
\cline { 2 - 3 } & Control Group & Experiment Group \\
\hline 1 & $72 \%$ & $79 \%$ \\
\hline 2 & $73 \%$ & $81 \%$ \\
\hline 3 & $71 \%$ & $83 \%$ \\
\hline 4 & $75 \%$ & $84 \%$ \\
\hline 5 & $74 \%$ & $86 \%$ \\
\hline Percentage & $73 \%$ & $83 \%$ \\
\hline
\end{tabular}

Based on table 3 above, the overall percentage of students' worksheet control group is $73 \%$, while the percentage of the total student activity of the control group using Students' activity sheet based on cooperative model of mind mapping type reached $83 \%$, entered in very high category. From these results, it can be concluded that students who learn by facilitated students' worksheet based cooperative model of mind mapping type is more active than students who learn to use students' worksheet commonly used in learning.

\section{The effectiveness of students' worksheet based on cooperative model of mind mapping type}

Effectiveness of the use of students' worksheet based on cooperative model of mind mapping type can be seen from student learning outcomes. In the beginning, students got pretest between the control group and the experimental group to find out the initial condition of the students. After the control group was given treatment with old students' worksheet and experimental class given cooperative type based on mind mapping given posttest to know the learning result of both groups. The pretest and posttest results will be tested using t-test. Before the t-test is done, the test performs a normality test and homogeneity test to determine whether the data is normally distributed or not. Homogeneity and normality test results showed that the data between the experimental class and the control class were normal and 
homogeneous distributed. While for the t-test results is presented in the following table:

TABLE V RESULT OF T-TEST DATA PRETEST STUDENTS LEARNING OUTCOME

\begin{tabular}{|l|l|l|l|l|}
\hline $\mathrm{T}_{\text {count }}$ & table & $\mathrm{Df}$ & Sig. (2-tailed) & $\alpha$ \\
\hline 1.141 & 2.024 & 38 & 0.268 & 0.05 \\
\hline
\end{tabular}

Based on the t-test results in the above table it can be seen that the data result of pretest (control class and experimental class) is 1.141 (df 38) and Sig. (2-tailed) of 0.268. For more details, the result of t-test of data of student learning achievement can be seen in appendix. The results show that 1,141 (df 38) $<t_{\text {table }} 2.024$ (df 38) and the value of Sig. (2tailed) $0,268>0.05$. This means that Ho is accepted and $\mathrm{Ha}$ is rejected. It can be conclude that there is no significant difference between the students' learning outcomes in the control class and the students in the experimental class

TABEL 5

T-TEST RESULT AFTER TREATMENT DATA (STUDENTS' WORKSHEET MIND MAPPING)

\begin{tabular}{|l|l|l|l|l|}
\hline count & $\mathrm{t}_{\text {able }}$ & $\mathrm{Df}$ & Sig. (2-tailed) & $\alpha$ \\
\hline 3.433 & 2.024 & 38 & 0.004 & 0.05 \\
\hline
\end{tabular}

Based on the result of t-test in the above table data of posttest result of student learning (control class and experiment class), it can be seen that the count is 3.290 (df 38) and Sig value (2-tailed) by 0.004 . The result shows count 3,290 $($ df 38) $>$ table 2.024 (df 38) and Sig value. (2-tailed) $0.004<0.05$ which means Ho is rejected and $\mathrm{Ha}$ is accepted. There are significant differences in student learning outcomes in the control class and experimental class. Based on the data calculated using the t-test, it can be concluded that students' activity sheet based on cooperative model of mind mapping type is effective to improve student learning outcomes, as evidenced by the significant differences of student learning outcomes in the experimental class and control class.

\section{CONCLUSION}

Based on the result of the research and discussion above, it can be concluded that: 1) students' worksheet based on cooperative model of mind mapping type is feasible to be used because the result of expert evaluation shows that students' worksheet based on cooperative model of mind mapping type can be used with little revision; 2) students' worksheet based on the cooperative model of mind mapping type is practically used in learning because it obtains very good predicate of the observer and student's response to the use of students' worksheet based on cooperative model of mind mapping type during learning; 3) Student activity using Students' worksheet based on cooperative model of mind mapping type is higher compared to students learning using old Students' activity sheet 4) Students' worksheet Based on cooperative model of mind mapping type is effective to improve student learning outcomes. The results of this study indicate that there is a significant difference between the students' learning outcomes in the experimental class and the control class. This is the evidenced from the results of t-test which shows that the value of $t$ arithmetic $>t$ table is $1.141>, 2.024$ so that Ho test decision is rejected and Ha is accepted;

\section{REFERENCES}

[1] Andi Prastowo. 2012. "Panduan Kreatif Membuat Bahan Ajar Inovatif". Yogyakarta: Diva Press.

[2] Che-Dilee.2014. "Worksheet Usage, Reading Achievement, Classes'Lack of Readiness,and Science Achievement: A Cross-Country Comparison". International Journal of Education in Mathematics,Science and Technology.volume 2 number 2

[3] Faturohman, Muhammad.2015. "Model-Model Pembelajaran Inovatif". Jogjakarta: AR-Ruzz media

[4] Dilekcelikler, zeynep aksan.2012. "The effect of the use of worksheet about aqueous solution reactions on pre-service elementary sciences". 4611-6414.

[5] Hanifah dan suhana.2010. "Konsep pembelajaran”. Bandung: PT Refika Aditama

[6] Sadirman.2015. "Interaksi Dan Motivasi Belajar Mengajar”. Jakarta : PT Raja grafindopersada.

[7] Saroj,jain.2015. "The comprehensive study of hoew mind mapping technique helps to understand consepts and ideas in science teching". International journal of scientffic and research publications, volume 5, issue 12

[8] Buzan, Tony. 2005. "Buku Pintar Mind Mapping”. Jakarta: PT. Gramedia Pustaka

[9] Ozgul,keles.2012. "Elementary teacher view on mind mapping". international journal of education vol 4 no 1

[10] Nikhilumar D.Parikh.2016. "Effectiveness of teaching through mind mapping teaching". The international journal of Indian psychology. Volume 3, issue 3, no 3

[11] Melor, Yunus, chanhua chin.2016. "The use of mind mapping strategy in Malaysian university English test (MUET) Writing”. Journal of creative education 619626. http://www.scrip.org/journsl/ce/ (diakses 6 januari 2018)

[12] Sugiono.2015. "Metode Penelitian Kuantitatif, kualitatif dan R\&D". Bandung: Alfabeta 